\title{
CHLOROPHYLL-PROTEINS OF TWO PHOTOSYSTEM I PREPARATIONS FROM MAIZE
}

\author{
by \\ ROBERTO BASSI", OTTO MACHOLD ${ }^{21}$ and DAVID SIMPSON \\ Department of Physiology, Carlsberg Laboratory, \\ Gamle Carlsberg Vej 10, DK 2500 Copenhagen Valby \\ and \\ 1) Dipartimento di Biologia, via Orto Botanico 35, 35100 Padova, Italy \\ ${ }^{2)}$ Zentralinstitut für Genetik und Kulturpflanzenforschung der Akademie \\ der Wissenschaft der DDR, 4325 Gatersleben, DDR
}

Keywords: Absorption spectra, chlorophyll-proteins, circular dichroism spectra, energy transfer, $77 \mathrm{~K}$ fluorescence emission spectra, gel electrophoresis, light-harvesting complexes of photosystem I, polypeptide composition, Zea mays

\begin{abstract}
Two photosystem I (PSI) preparations were purified by non-denaturing SDS-PAGE or sucrose gradient ultracentrifugation and examined as to their chlorophyll-protein composition. In both preparations a minimum of two chlorophyll-proteins can be distinguished in addition to the $110 \mathrm{kD} P-700 \mathrm{Chl}_{a}-\mathrm{P} 1$ complex. One (LHCI-730) is a chlorophyll-protein ( $\mathrm{Mr} 40 \mathrm{kD}$ ) having a high chlorophyll $a / b$ ratio, and a major $77 \mathrm{~K}$ fluorescence peak at 730 $\mathrm{nm}$. It consists of three polypeptides with apparent molecular weights of $21,22.5$ and $24 \mathrm{kD}$. Another chlorophyll-protein (LHCI-680) with a lower molecular weight (Mr $25 \mathrm{kD}$ ) fluoresces at $77 \mathrm{~K}$ with a maximum at $680 \mathrm{~nm}$. This chlorophyll-protein has a high chlorophyll $b$ content and two constituent polypeptides of 20 and 25 $\mathrm{kD}$. Absorption, $77 \mathrm{~K}$ fluorescence and circular dichroism spectra of the PSI related chlorophyll-proteins are presented and compared with those of photosystem II chlorophyll-proteins from maize thylakoids. We propose a model for energy transfer in the photosystem I reaction centre with the following sequence: $\mathrm{LHCl}-730 \rightarrow \mathrm{LHCl}-680$ $\rightarrow \mathrm{Chl}_{a}-\mathrm{P} 1$. LHCl-680 acts as a connecting antenna which can also transfer energy from $\mathrm{Chl}_{a / b}-\mathrm{P} 2$. This model was used to interpret the $77 \mathrm{~K}$ fluorescence emission from two barley mutants.
\end{abstract}

\section{INTRODUCTION}

In 1975 THORNBER reported the isolation of two chlorophyll-proteins by SDS-PAGE: CPI and CPII (39). CPI (Chl ${ }_{a}$ P1) binds only chlorophyll $a$ and has been identified as the photosystem I (PSI) reaction centre (3). CPII ( $\mathrm{Chl}_{a / b}$ P2) binds both chlorophyll $a$ and $b$. It is the major light-harvesting protein and is mainly associated with photosystem II (PSII) in the appressed regions of grana thylakoids.

Improvement of analytical methods led initially to the detection of two other less stable chlorophyll-proteins which bind only chlorophyll $a$ and which are associated with the PSII reaction centre: $\mathrm{Chl}_{a}-\mathrm{P} 2$ and $\mathrm{Chl}_{a}-\mathrm{P} 3(2,7,14$, 29). Chlorophyll $a / b$-binding chlorophyll-

Abbreviations: $\mathrm{CD}$ = circular dichroism; $\mathrm{LHCI}=$ light-harvesting complex of photosystem I; LHCII = light-härvesting complex of photosystem II; PAGE = polyacrylamide gel electrophoresis; PS = photosystem ; SDS = sodium dodecylsulphate; tricine $=\mathrm{N}$-(tris(hydroxymethyl)methyl) glycine; Tris $=$ tris-(hydroxymethyl) amino methane . 
proteins, described as either oligomers of CPII $(2,7,29)$ or as a new chlorophyll $a / b$ complex $(28,29)$, were also resolved.

In the last few years the presence of another chlorophyll $a / b$-binding, light-harvesting chlorophyll-protein associated with PSI (LHCI), has been reported $(21-24,33,36,41)$ which has a high chlorophyll $a / b$ ratio and apoproteins in the 20-25 kD molecular weight range. In a previous paper (11), the chlorophyll-proteins of bundle sheath and mesophyll plastids of maize were examined and a similar chlorophyll $a / b$-binding chlorophyll-protein was shown to be present in both types of plastids. The holoprotein had a relative molecular weight of about $40 \mathrm{kD}$ and after re-electrophoresis under denaturing conditions was shown to contain three polypeptides with molecular weights of $21,22.5$ and $24 \mathrm{kD}$. This chlorophyll-protein has been successfully isolated in pure form by mild SDS-PAGE of bundle sheath thylakoids (11). Contamination by $\mathrm{Chl}_{a}-\mathrm{P} 2$ and $\mathrm{Chl}_{a}-\mathrm{P3}$ which have similar electrophoretic mobilities is avoided, because they are both absent from maize bundle sheath chloroplasts (12). The chlorophyll-protein designated $\mathrm{Chl}_{a / b}-\mathrm{P} 3$ in (11) according to the terminology of (29) fluoresces with a major peak at $730 \mathrm{~nm}$ at $77 \mathrm{~K}$, has a red absorption peak at $674 \mathrm{~nm}$, and is a light-harvesting chlorophyllprotein of PSI (also called LHCI).

In this study we have examined two PSI preparations isolated by two independent methods which preserve, as much as possible, the native conditions of the complex as determined by $P-700$ activity and low temperature fluorescence emission spectra. $\mathrm{Chl}_{a}-\mathrm{Pl}{ }^{*}$ was isolated by non-denaturing SDS-PAGE of octylglucoside-solubilized thylakoids $(11,12)$, and a second PSI preparation was isolated by sucrose gradient ultracentrifugation of Triton $\mathrm{X}-100$ solubilized thylakoids as described by MuLLET et al. (30). The chlorophyll-proteins of these preparations have been separated by SDSPAGE under conditions which avoid the dissociation of chlorophyll-protein complexes into their component polypeptides. The chlorophyll-proteins were isolated from gels and analyzed for their polypeptide composition by SDSPAGE in the presence of $6 \mathrm{M}$-urea and by spectroscopy. We conclude that the PSI complex contains two chlorophyll $a / b$-proteins which differ from the main light-harvesting complex of PSII.

In this paper we have reported, for the first time, the circular dichroism (CD) spectra of all the chlorophyll-proteins that can currently be resolved from thylakoids. CD is the differential absorption of right- and left-handed circularly polarized light and is an indicator of pigmentpigment and/or pigment-protein interactions important in the mutual orientation of the chromophores in the protein. This technique appears particularly promising in chlorophyllprotein studies because of its ability to distinguish between pigment species with similar absorption properties but different orientations.

\section{MATERIALS AND METHODS}

\subsection{Thylakoids}

Two weeks old, greenhouse-grown maize plants (Zea mays L.) were homogenized in 0.1 M-tricine/ $\mathrm{NaOH} \mathrm{pH} 7.8,0.4 \mathrm{M}$-sorbitol. The slurry was filtered through two layers of $20 \mu \mathrm{m}$ nylon net and pelletted at $5000 \times \mathrm{g}$ for $5 \mathrm{~min}$. The pellet was washed twice with $10 \mathrm{mM}$-sodium pyrophosphate $\mathrm{pH} 7.4$, then with 2 mM-tricine/ $\mathrm{NaOH}$ pH 7.8. The washed thylakoids were resuspended at a chlorophyll concentration of 1 $\mathrm{mg} \cdot \mathrm{ml}^{-1}$ in $10 \%$ glycerol, $65 \mathrm{~mm}-\mathrm{Tris} / \mathrm{HCl} \mathrm{pH}$ 6.8, 5 mM-dithiothreitol.

Membranes from bundle sheath thylakoids were prepared as previously described (12).

\subsection{PSI preparation by sucrose gradient ultracentrifugation}

A native PSI preparation was prepared by gradient ultracentrifugation of Triton X-100 solubilized thylakoids as described in (30), with the exception that $0.6 \%$ Triton X-100 instead of $0.7 \%$ was used in the solubilization step.

An antenna I-depleted PSI particle was prepared by dialyzing the native PSI preparation for $3 \mathrm{hrs}$ against $5 \mathrm{~mm}$-tricine $\mathrm{pH} 8.0,150$ $\mathrm{mM}-\mathrm{NaCl}$ and then adding dodecylmaltoside to $1 \%$. The PSI particles were recovered as an high mobility, non-fluorescent, apple-green band in the lower $2 / 3$ of the tube, after 18 hrs sucrose 
gradient ultracentrifugation at $40,000 \times \mathrm{g}$ in a Beckman SW 40 rotor at $4{ }^{\circ} \mathrm{C}$. The gradient was 0.1 to $1 \mathrm{M}$-sucrose in $5 \mathrm{~mm}$-tricine $\mathrm{pH} 8.0$ including $1 \%$ dodecylmaltoside. The PSIcontaining band was recovered with a syringe and used immediately or was frozen in liquid nitrogen and stored at $-80{ }^{\circ} \mathrm{C}$ until further analysis.

\subsection{Electrophoresis}

Solubilization of thylakoids with octylglucoside and non-denaturing, tube SDS-PAGE was carried out as previously described $(11,12)$. The $\mathrm{Chl}_{a}-\mathrm{P} 1^{*}$ containing band was excised from the gel and incubated for $10 \mathrm{~min}$ at $0^{\circ} \mathrm{C}$ in 150 $\mathrm{mM}-\mathrm{NaCl}$ and loaded onto an identical gel tube with the exception that $150 \mathrm{mM}-\mathrm{NaCl}$ was included in the stacking gel. Gels were run for 2.5 hrs at $25 \mathrm{~mA} / 18$ tubes at $4{ }^{\circ} \mathrm{C}$ or lower. For re-electrophoresis, gels were not prerun. Green bands were excised from the second gel and used immediately for elution or frozen in liquid nitrogen until further analysis.

The PSI preparation (section 2.2) was dialyzed for $3 \mathrm{hrs}$ against $150 \mathrm{~mm}-\mathrm{NaCl}, 5 \mathrm{~mm}$-tricine $\mathrm{pH}$ 8.0 and concentrated to $0.5 \mathrm{mg} \mathrm{chl} \cdot \mathrm{ml}^{-1}$ in an Amicon ultrafiltration cell at $4{ }^{\circ} \mathrm{C} .25 \mu$ of the concentrated PSI suspension was loaded onto a tube gel with $\mathrm{NaCl}$ in the stacking gel as described above. Denaturing SDS-PAGE in the presence of $6 \mathrm{M}$-urea was as described (11). Apparent molecular weights were obtained by comparison with the following standards: phosphorylase $b(94 \mathrm{kD})$, bovine serum albumin (67 kD), ovalbumin (43 kD), carbonic anhydrase (30 kD), trypsin inhibitor $(20 \mathrm{kD})$, $\alpha$-lactosidase (14.4 kD).

\subsection{Spectroscopy}

For absorption and circular dichroism spectroscopy, gel slices were ground in a small volume of glass distilled water and incubated overnight at $4{ }^{\circ} \mathrm{C}$. Gel debris were removed by filtering through $20 \mu \mathrm{m}$ nylon net and centrifuging $10 \mathrm{~min}$ in an Eppendorf microfuge. Absorption and circular dichroism spectra were taken as previously described (11) with the exception that a $10 \mathrm{~mm}$ optical pathlength, quartz cuvette was used instead of a $2 \mathrm{~mm}$ one, because of the low concentration of some of the samples eluted from gels. The accuracy of the wavelength calibration was checked at $490 \pm 1$ $\mathrm{nm}$ with $\left[\mathrm{Co}(\mathrm{CN})_{3}\right]^{3+}$.

Fluorescence emission spectra at $77 \mathrm{~K}$ were taken directly from gel slices as described (11).

\subsection{Other}

Chlorophyll concentration and chlorophyll $a / b$ ratios were determined as described by ARNON (9).

\section{RESULTS}

Table I presents an overview of the names and functions of the green bands obtained by electrophoresis after solubilization with the nonionic detergent octyl $\beta$,D-glucopyranoside. The bands are listed in order of increasing electrophoretic mobility. For each green band, the subunit composition determined from re-electrophoresis, and Coomassie blue-staining polypeptide composition with apparent molecular weights obtained in this study are given in the last two columns of the table.

\subsection{Preparation and fractionation of $\mathrm{Chl}_{\boldsymbol{a}}-\mathrm{P1}$ *}

Solubilization of thylakoids with low amounts of the non-ionic detergent octyl $\beta, D-g l u c o-$ pyranoside (detergent:chlorophyll $=20: 1 \mathrm{w} / \mathrm{w}$ ) in low concentration buffer yielded a high amount of chlorophyll associated with $\mathrm{Chl}_{a}-\mathrm{Pl}$ * (Figure 1A). In some experiments almost all of the chlorophyll associated with PSI was found in $\mathrm{Chl}_{a}-\mathrm{P} 1^{*}$, while the amount of $\mathrm{Chl}_{a}-\mathrm{Pl}$ and $\mathrm{Chl}_{a / b}-\mathrm{P} 3$ was very much decreased. The $\mathrm{Chl}_{a}$ $\mathrm{P}^{*}$ band excised from the gel showed $730 \mathrm{~nm}$ fluorescence emission at $77 \mathrm{~K}$ (Figure 2). Its absorption spectrum showed shoulders at 472 and $480 \mathrm{~nm}$, indicating the presence of both chlorophyll $b$ and carotenoids. These features were particularly evident if the $\mathrm{Chl}_{a}-\mathrm{P} 1^{*}$ and $\mathrm{Chl}_{a}-\mathrm{Pl}$ spectra were compared (Figure 3 ), the latter showing no chlorophyll $b$ contribution. The polypeptide composition of the $\mathrm{Chl}_{a}-\mathrm{Pl}{ }^{*}$ is shown in Figure 4B, track 8. The pattern included the $110 \mathrm{kD}$ reaction centre of PSI, five 
R. BASSI et al.: Chlorophyll-proteins of photosystem I

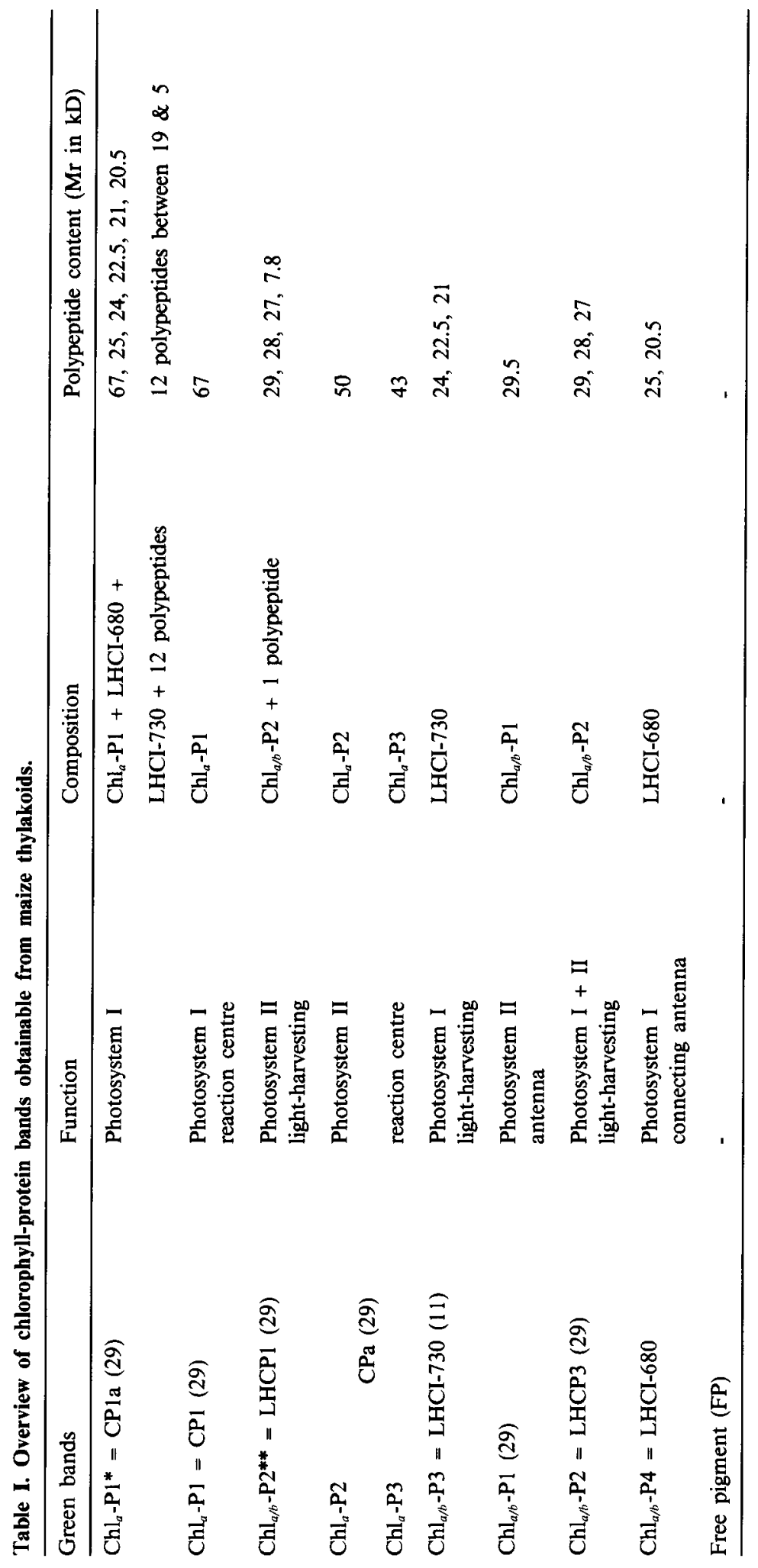



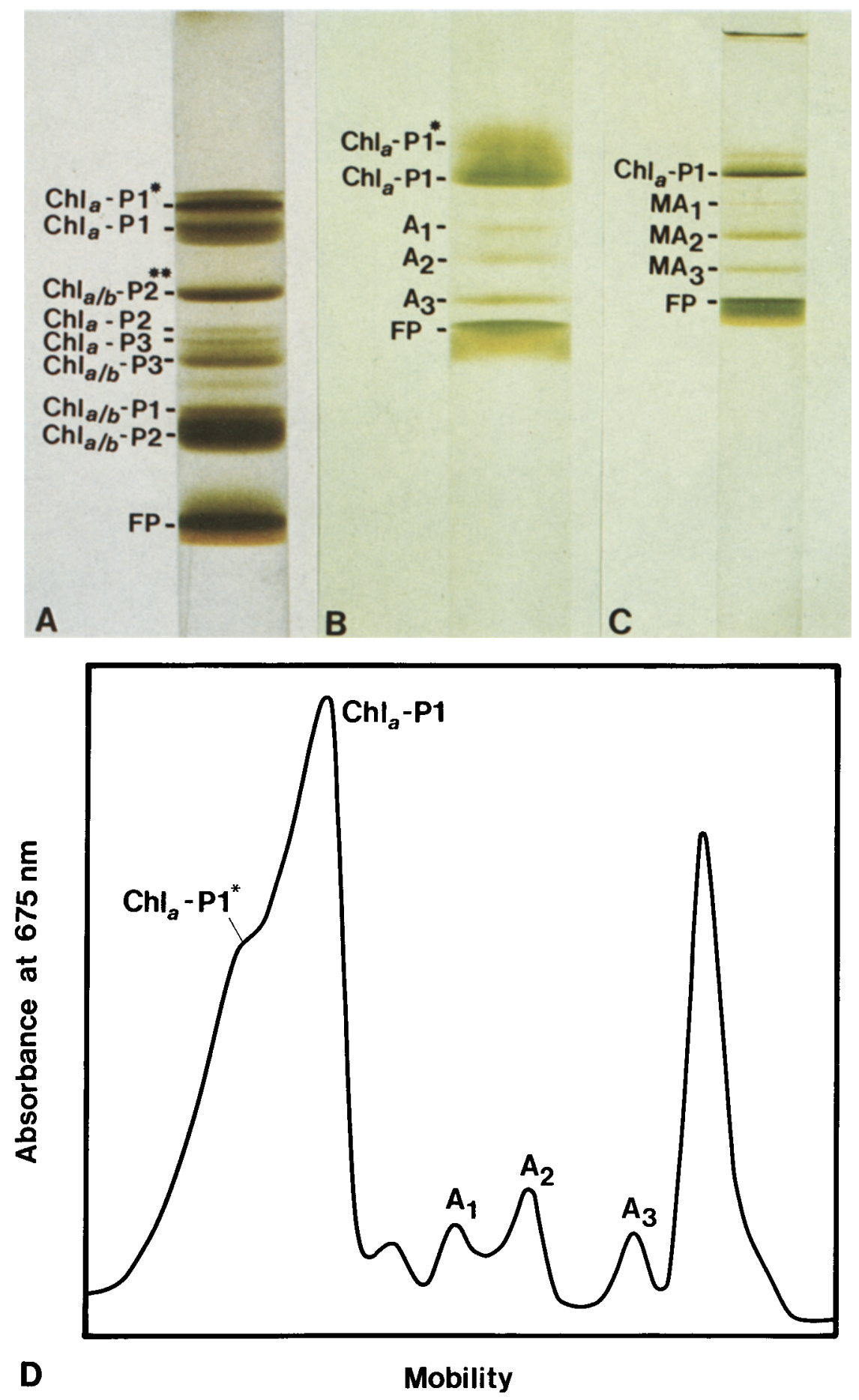

Figure 1. A: Non-denaturing SDS-PAGE of the chlorophyll-proteins from maize thylakoids. The designations and composition of the green bands are given in Table I. B: The uppermost band from (A) was cut from the gel and re-run in mildly dissociating conditions $(150 \mathrm{~mm}-\mathrm{NaCl}$ in the stacking gel). $\mathrm{C}$ : Mildly dissociating SDS-PAGE of PSI-110 particles. D: densitometer tracing of the gel in (B). A1 = dimer of A2: A2, MA2 = LHCI-730: A3, MA3 = LHCI-680. 


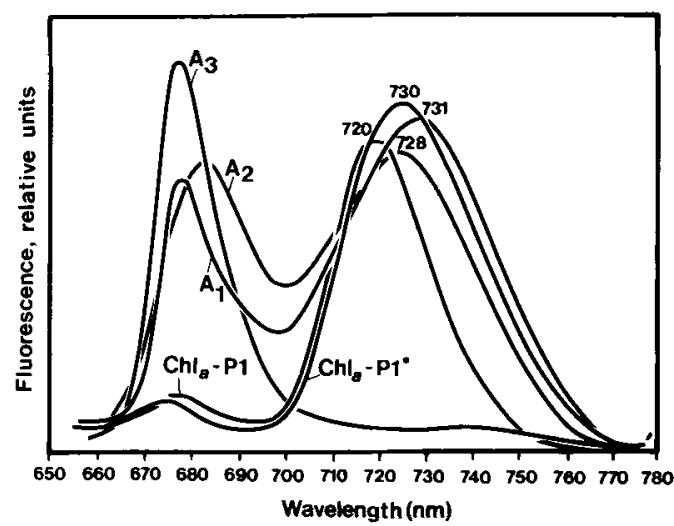

Figure 2. In situ $77 \mathrm{~K}$ fluorescence emission spectra of $\mathrm{Chl}_{a}-\mathrm{Pl}^{*}$ and of the chlorophyll-proteins obtained by re-electrophoresis (Figure 1B). Fluorescence was excited with a broad band blue light. The slit width for emission was $5 \mathrm{~nm}$.

polypeptides with molecular weights between 20 and $25 \mathrm{kD}$ and seven other polypeptides with lower molecular weights.

When the $\mathrm{Chl}_{a}-\mathrm{P} 1^{*}$ band was excised, soaked $15 \mathrm{~min}$ in $150 \mathrm{mM}-\mathrm{NaCl}$, and re-run in a tube gel with $150 \mathrm{mM}-\mathrm{NaCl}$ in the stacking gel, four green bands were present, plus the free pigment band at the front (Figure 1B). The second highest molecular weight band was identified as $\mathrm{Chl}_{\mathrm{a}}-\mathrm{P} 1$ from its $720 \mathrm{~nm}$ emission at $77 \mathrm{~K}$, and the exclusive presence of chlorophyll $a$ with a 678 $\mathrm{nm}$ red peak in the absorption spectrum. It contained only the $110 \mathrm{kD}$ PSI reaction centre protein, which has a $67 \mathrm{kD}$ apoprotein.

The two green bands with mobilities corresponding to about $60 \mathrm{kD}$ (A1) and $40 \mathrm{kD}$ (A2), respectively, had very similar $77 \mathrm{~K}$ fluorescence emission spectra with maxima at 731 and $728 \mathrm{~nm}$ (Figure 2). Their absorption spectra were identical and revealed a higher chlorophyll $b$ concentration than that of the starting material $\left(\mathrm{Chl}_{a}-\mathrm{P} 1^{*}\right)$ (Figure 3 ). SDSPAGE in the presence of $6 \mathrm{M}$-urea, showed that the A1 and A2 bands both contained three polypeptides with molecular weights of $24,22.5$ and $21 \mathrm{kD}$ (bands $\mathrm{B}, \mathrm{C}$ and $\mathrm{D}$, respectively, in Figure $4 \mathrm{~A}$, tracks 3,4 ). It is likely, therefore, that $A 1$ is a dimer of $A 2$. The fact that the apparent molecular weight of $A 1$ is not twice that of $A 2$ is not surprising because of the known anomalous

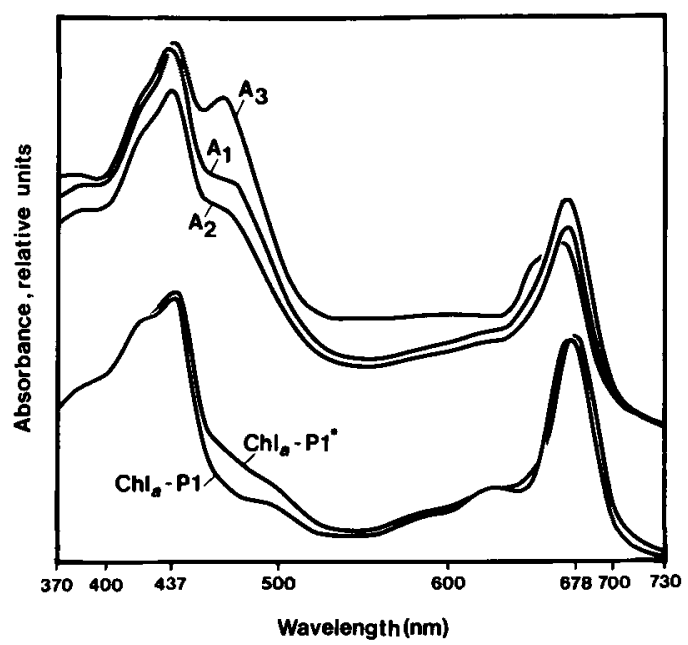

Figure 3. Room temperature absorption spectra of $\mathrm{Chl}_{a}-\mathrm{Pl}^{*}$ and of the chlorophyll-proteins obtained from re-electrophoresis of $\mathrm{Chl}_{a}-\mathrm{P} 1^{*}$ in mildly dissociating conditions, as in Figure 1B. Chlorophyll-proteins were eluted from gel slices with glass distilled water overnight at $4{ }^{\circ} \mathrm{C}$, and spectra were obtained with an Aminco DW2a spectrophotometer. The slit width was $2 \mathrm{~nm}$, pathlength $10 \mathrm{~mm}$.

migration of chlorophyll-proteins in in SDSPAGE (18). In view of the large differences in apparent molecular weights of these chlorophyll-proteins and their component polypeptides it is clear that all three polypeptides are present in the native complex. It is not obvious whether only one or all three bind chlorophyll.

The green band with the highest mobility (A3) had a $77 \mathrm{~K}$ fluorescence emission maximum at $680 \mathrm{~nm}$ and an absorption spectrum (Figure 3) showing a very high chlorophyll $b$ content (chlorophyll $a / b$ ratio of about 1 ). The interpretation of its polypeptide composition was complex because the short distance between this green band and the free pigment band at the front made it difficult to excise the chlorophyllprotein band without contamination from low molecular weight polypeptides migrating near the front. The green A3 band contained two major polypeptides with molecular weights of 25 and $20 \mathrm{kD}$ (bands $\mathrm{A}$ and $\mathrm{E}$, respectively, Figure $4 \mathrm{~A}$, track 5), neither of which was present in the green $\mathrm{A} 1$ and $\mathrm{A} 2$ bands, as well as other low molecular weight polypeptides that were also 


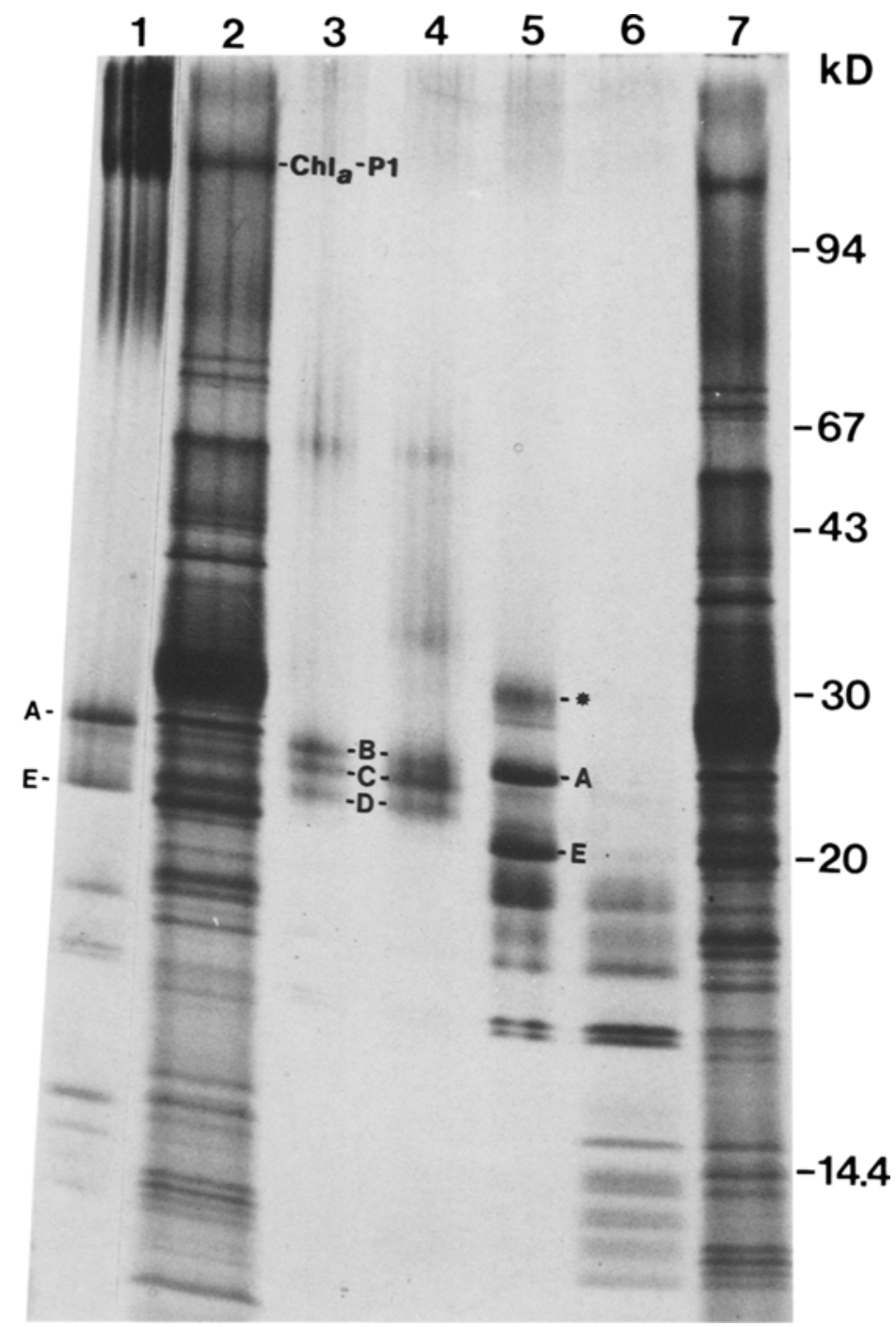

Figure 4A. SDS-PAGE in the presence of $6 \mathrm{M}$-urea of chlorophyll-proteins excised from tube gels (Figure 1B). Track 1: $\mathrm{Chl}_{a}-\mathrm{P} 1^{*}$. Track 2: thylakoids. Track 3: A1 band (dimer of A2). Track 4: A2 band (LHCI-730). Track 5: A3 band (LHCI-680). Track 6: FP band. Track 7: thylakoids. The uppermost band in track $5\left({ }^{*}\right)$ is considered a contaminant as it was not present in other experiments.

present in the electrophoresis of the free pigment band (Figure 4A, track 6). The similarity in the molecular weights of the $\mathrm{A} 3$ holoprotein and the two polypeptides found after re-electrophoresis of the excised gel band may mean that one of the polypeptides is a contaminant.

It is thus clear on the basis of electrophoretic mobility, chlorophyll $a / b$ ratio, polypeptide composition and $77 \mathrm{~K}$ fluorescence, that there are two different light-harvesting chlorophyll $a / b$-proteins associated with photosystem I. These are named $\mathrm{Chl}_{a / b}-\mathrm{P} 3$ and $\mathrm{Chl}_{a / b}-\mathrm{P4}$ (Table I) after the nomenclature system of (29), but for clarity will be referred to as LHCI-730 and LHCI-680 in this paper. The number refers to the wavelength of the $77 \mathrm{~K}$ fluorescence emission peak.

In some experiments an additional green 
R. BASSI et al.: Chlorophyll-proteins of photosystem I

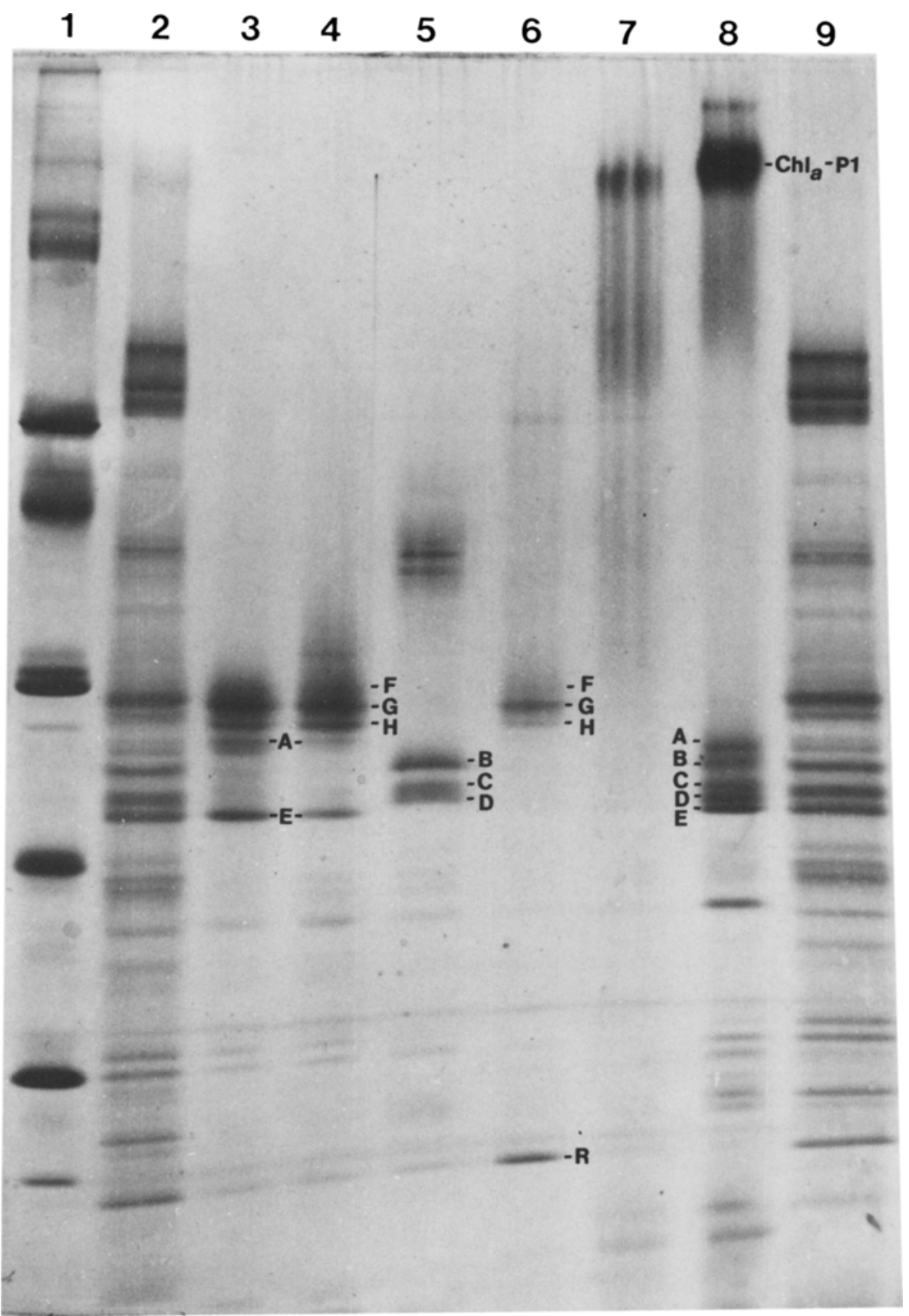

Figure 4B. SDS-PAGE in the presence of $6 \mathrm{M}$-urea of chlorophyll-proteins obtained from bundle sheath membranes by non-denaturing SDS-PAGE. Track 1: molecular weight markers. Track 2: bundle sheath thylakoids. Tracks 3 and 4: $\mathrm{Chl}_{a / b}-\mathrm{P} 2+\mathrm{Chl}_{a / b}-\mathrm{P} 4$ (LHCI-680). Track 5: $\mathrm{Chl}_{a / b}-\mathrm{P3}$ (LHCI-730). Track 6: $\mathrm{Chl}_{a / b}-\mathrm{P}{ }^{* *}$. Track 7: $\mathrm{Ch}_{a}-\mathrm{P} 1$. Track 8: $\mathrm{Chl}_{a}-\mathrm{P} 1^{*}$. Track 9: bundle sheath thylakoids. 
band having a mobility between $\mathrm{Chl}_{a}-\mathrm{P} 1$ and $\mathrm{A} 1$ was seen. This band had a fluorescence emission peak at $732 \mathrm{~nm}$ and an absorption spectrum and polypeptide composition identical to those of the A1 and A2 bands. This confirms the tendency of this chlorophyll-protein to be found as higher molecular weight forms. When gel slices from the free pigment front were reelectrophoresed in a urea gel system, the low molecular weight polypeptides of $\mathrm{Chl}_{a}-\mathrm{P} 1^{*}$ were separated. Twelve bands with molecular weights between 19 and $5 \mathrm{kD}$ were resolved (Figure 4A, track 6), indicating that the polypeptides of $\mathrm{Chl}_{a}-\mathrm{P} 1^{*}$ were more numerous than shown in Figure 4B, track 8.

A small amount of $\mathrm{Chl}_{a}-\mathrm{P} 1^{*}$ was still present after re-electrophoresis (Figure 1B and 1D). When this was re-run under denaturing conditions and compared with the starting material (Figure 4A, track 1; cf Figure 4B, track 8), a specific decrease was observed in the amounts of polypeptides B, C and D of LHCl-730 (= green bands $A 1$ and $A 2$ ). The 25 and $20 \mathrm{kD}$ polypeptides (A and E) of LHCI-680 were apparently more strongly bound to the $\mathrm{Chl}_{\alpha}-\mathrm{Pl}$ reaction centre.

\subsection{Fractionation of PSI particles from sucrose gradient ultracentrifugation} (prepared according to MULLET et al. (30)).

The PSI preparation from sucrose gradient ultracentrifugation of Triton X-100 solubilized thylakoids showed characteristics similar to $\mathrm{Chl}_{a}-\mathrm{P} 1^{*}$ in respect to $77 \mathrm{~K}$ fluorescence emission (730 nm peak) (Figure 5) and absorption spectrum (Figure 6). The chlorophyll $a / b$ ratio was 5.5 . When this preparation was electrophoresed under mildly dissociating conditionis as described for $\mathrm{Chl}_{a}-\mathrm{Pl} 1^{*}$, there were four green bands as well as the yellow-green free pigment front (Figure 1C). The pattern was thus similar to that after the re-electrophoresis of $\mathrm{Chl}_{a}-\mathrm{P} 1^{*}$, although the second band in order of mobility (MA1) was much fainter than the Al band.

The highest molecular weight band was the same as $\mathrm{Chl}_{a}-\mathrm{Pl}$ with respect to $77 \mathrm{~K}$ fluorescence emission, absorption spectrum and polypeptide composition. The second band

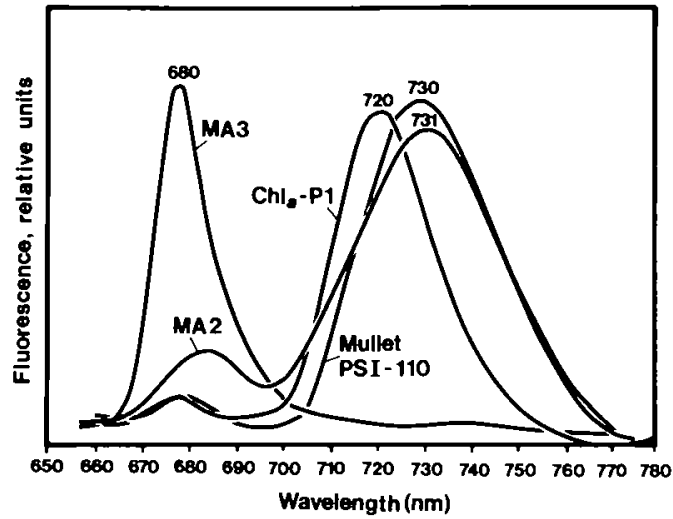

Figure 5. In situ $77 \mathrm{~K}$ fluorescence emission spectra of chlorophyll-proteins resolved after electrophoresis of the PSI-1 10 particles.

(MA1) fluoresced with a peak at $680 \mathrm{~nm}$, its absorption spectrum showed only chlorophyll $a$ and it contained a single protein with a molecular weight of $67 \mathrm{kD}$. In addition, the eluted band showed no optical activity when examined for circular dichroism, which was at variance with the properties of the $\mathrm{Al}$ band from $\mathrm{Chl}_{a}$ $\mathrm{P} 1^{*}$ (see below). This indicates that the chlorophyll was randomly organized, so that the MA I band has no properties in common with the $\mathrm{Al}$ band.

The third green band (MA2) was very similar to the A2 band (LHCI-730), with $730 \mathrm{~nm}$ fluorescence at $77 \mathrm{~K}$ and an absorption spectrum revealing the presence of both chlorophyll $a$ and $b$ contributions. Three polypeptides

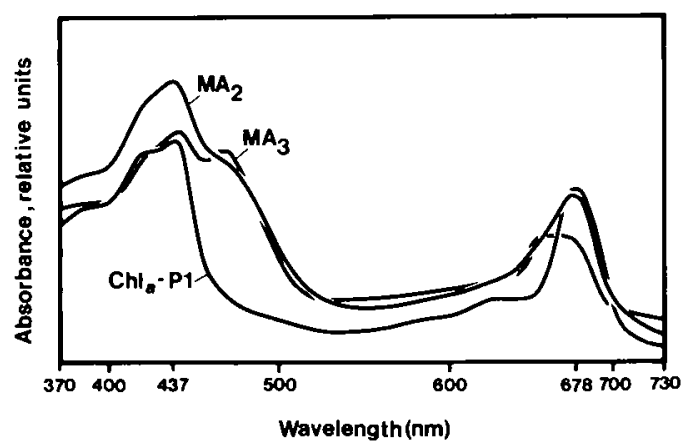

Figure 6. Absorption spectra of the chlorophyll-proteins eluted after electrophoresis of the PSI-110 preparation in mildly dissociating conditions. 


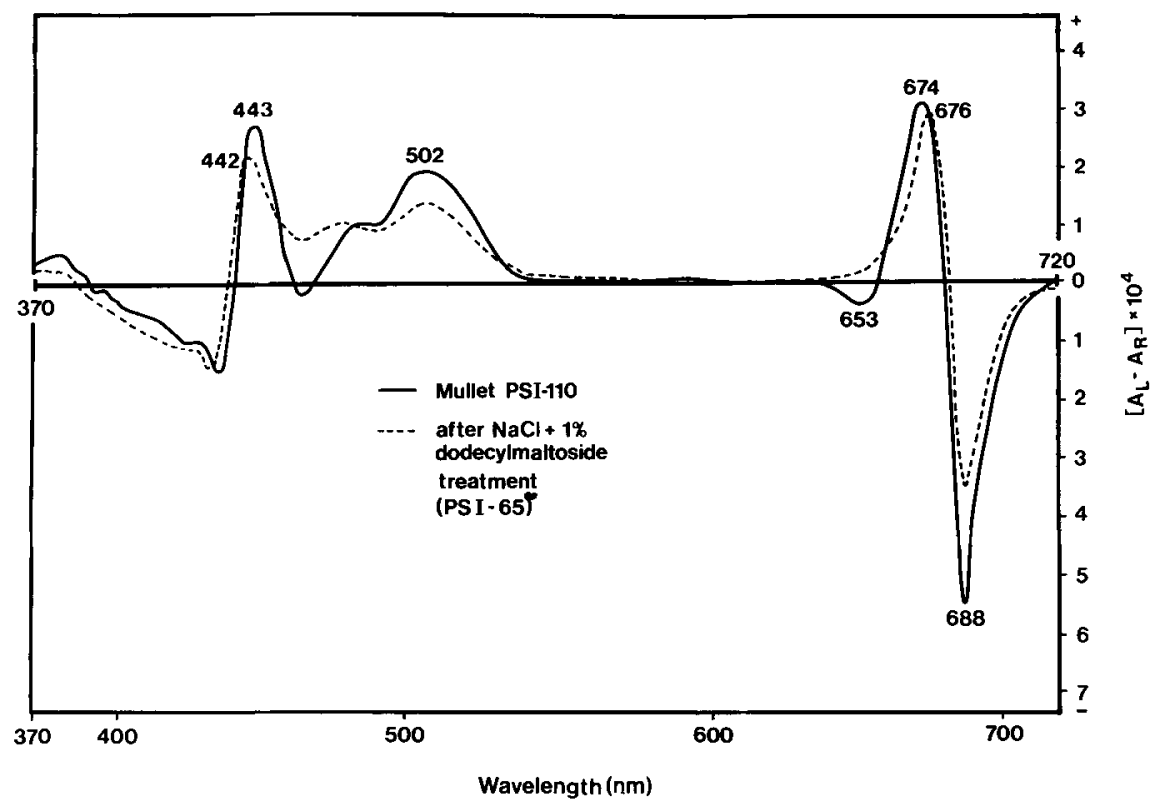

Figure 7. Circular dichroism spectra of the PSI-1 10 preparation before and after depletion of the antenna I by dialysis against $\mathrm{NaCl}$ and treatment with dodecylmaltoside. Slit width was $0.5 \mathrm{~nm}$. The chlorophyll concentration was $20 \mu \mathrm{g} \cdot \mathrm{ml}^{-1}$, pathlength $10 \mathrm{~mm}$.

of $21,22.5$ and $24 \mathrm{kD}$ were present in this band. In addition two other polypeptides of 38 and 42 $\mathrm{kD}$ were found. The fourth green band (MA3) was identical to the A3 band (LHCI-680) from $\mathrm{Chl}_{a}-\mathrm{P} 1^{*}$ with respect to $77 \mathrm{~K}$ fluorescence emission, absorption and polypeptide composition.

When chlorophyll-proteins of bundle sheath thylakoids were separated by mild SDS-PAGE and the excised gel slices containing chlorophyllproteins were re-run in the presence of $6 \mathrm{M}$-urea (11), the $\mathrm{Chl}_{a / b}-\mathrm{P} 3$ band had the spectral characteristics of LHCI-730, i.e., those of A1, A2 and MA2, and also consisted of three polypeptides of 21, 22.5 and $24 \mathrm{kD}$ (Figure 4B, track 5). We conclude that the green bands A2, MA2 and $\mathrm{Chl}_{a / b}$-P3 represent the same chlorophyllprotein, A1 being a oligomeric form.

\subsection{Circular dichroism of chlorophyll-proteins separated by non-denaturing SDS-PAGE from maize thylakoids and PSI prepara- tions}

$\mathrm{CD}$ spectra in the visible region have been reported from $\mathrm{Chl}_{a / b}-\mathrm{P} 2$ preparations (37). More recently, $C D$ spectra have been described for various PSI preparations (21) and for LHCI (21, 24). One of the interesting features of the published spectra was a negative peak at $647 \mathrm{~nm}$ from the native PSI preparation that appeared to be indicative of the presence of chlorophyll $b$. In order to check this assignment, we have examined different native and LHCI depleted PSI preparations, as well as the other PSI-associated chlorophyll-proteins. In addition, we have compared these spectra with those of other chlorophyll-proteins isolated from maize thylakoids by mild SDS-PAGE, to determine if a common pigment organization could be recognized in the light-harvesting chlorophyllproteins compared with the reaction centre ones. Absorption and fluorescence emission spectra of the chlorophyll-proteins from maize thylakoids as well as their polypeptide composition have been published (11).

In Figure 7, CD spectra of PSI prepared by gradient ultracentrifugation are shown before and after treatment with $\mathrm{NaCl}$ and dodecylmaltoside. The antenna-depleted preparation fluoresced at $720 \mathrm{~nm}$ at $77 \mathrm{~K}$ and contained 5 


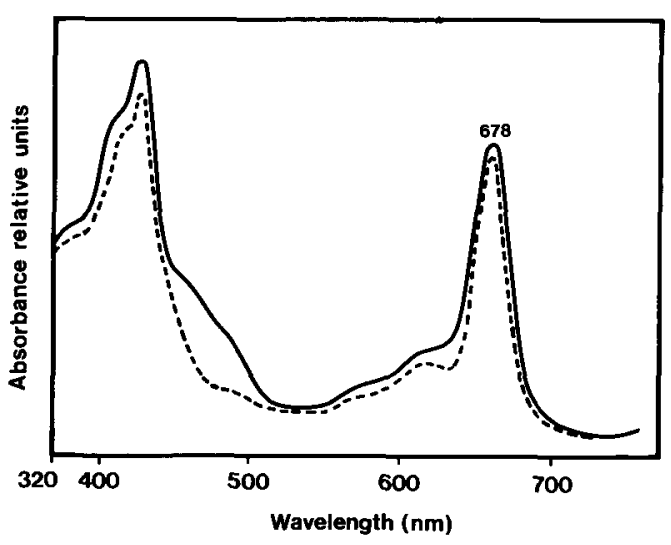

Figure 8. Absorption spectra of the PSI-110 preparation before and after depletion of the antenna I.

polypeptides of $110,32,19 \mathrm{kD}$ and a doublet at about $17 \mathrm{kD}$ exactly corresponding to PSI-65 (30). From the absorption spectrum (Figure 8), the chlorophyll $b$ contribution was not present and the polypeptides in the $20-25 \mathrm{kD}$ range were absent from the preparation.

The main differences between the native and antenna-depleted preparations were the disap- pearance of a negative signal at $653 \mathrm{~nm}$ and a reduction of the intensity of another one at $688 \mathrm{~nm}$. Another reproducible feature was a small shift in opposite directions of the two positive peaks at 442 and $675 \mathrm{~nm}$. They were also narrower, as if a component with a maximum near the main signal were removed. Very similar results were obtained when the $C D$ spectra of $\mathrm{Chl}_{a}-\mathrm{P} 1^{*}$ and $\mathrm{Chl}_{a}-\mathrm{Pl}$ were examined (Figure 9). The $\mathrm{Chl}_{a}-\mathrm{P} 1^{*}$ preparation was very similar to the PSI from gradient ultracentrifugation, while the $\mathrm{Chl}_{a}-\mathrm{Pl}$ was much simpler in composition compared with the antenna-depleted gradient fraction since it only contained the $110 \mathrm{kD}$ PSI reaction centre protein. In both antenna-depleted preparations, $C D$ signals were decreased in intensity but still present at 480 and $503 \mathrm{~nm}$, indicating the presence of carotenoids in the PSI reaction centre.

When the $730 \mathrm{~nm}$ fluorescing complexes, namely $\mathrm{A} 1$ and $\mathrm{A} 2$ from $\mathrm{Chl}_{a}-\mathrm{P} 1^{*}$ and MA2 from the PSI-1 10 preparation, were eluted from the gel and examined for $C D$, all had the same spectra, as exemplified by MA2 (Figure 10). The spectra obtained from the $680 \mathrm{~nm}$ fluorescing chlorophyll-proteins (A3 and MA3) were identi-

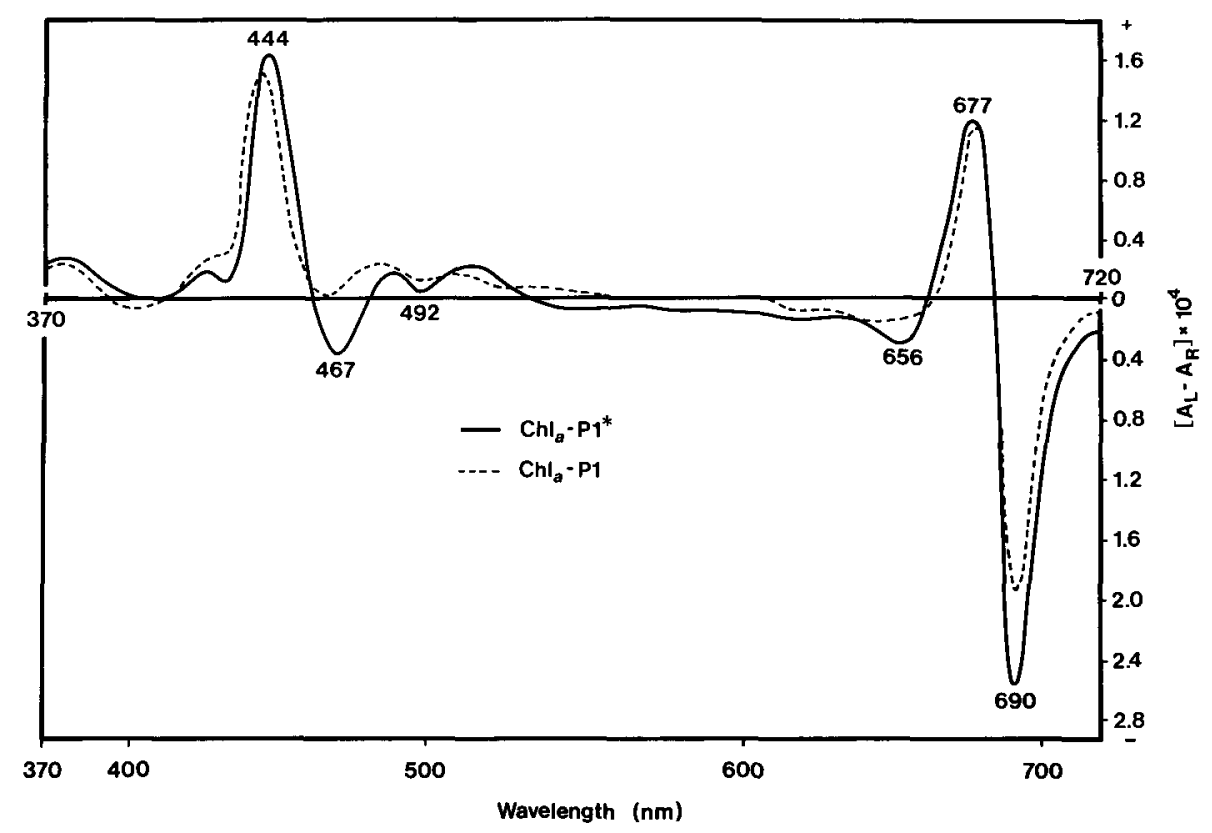

Figure 9. Circular dichroism spectra of the eluted $\mathrm{Chl}_{a}-\mathrm{P} 1^{*}$ and $\mathrm{Chl}_{a}-\mathrm{Pl}$ bands. Chlorophyll concentration was $10 \mu \mathrm{g} \cdot \mathrm{ml}^{-1}$, slit width $=1 \mathrm{~nm}$. 


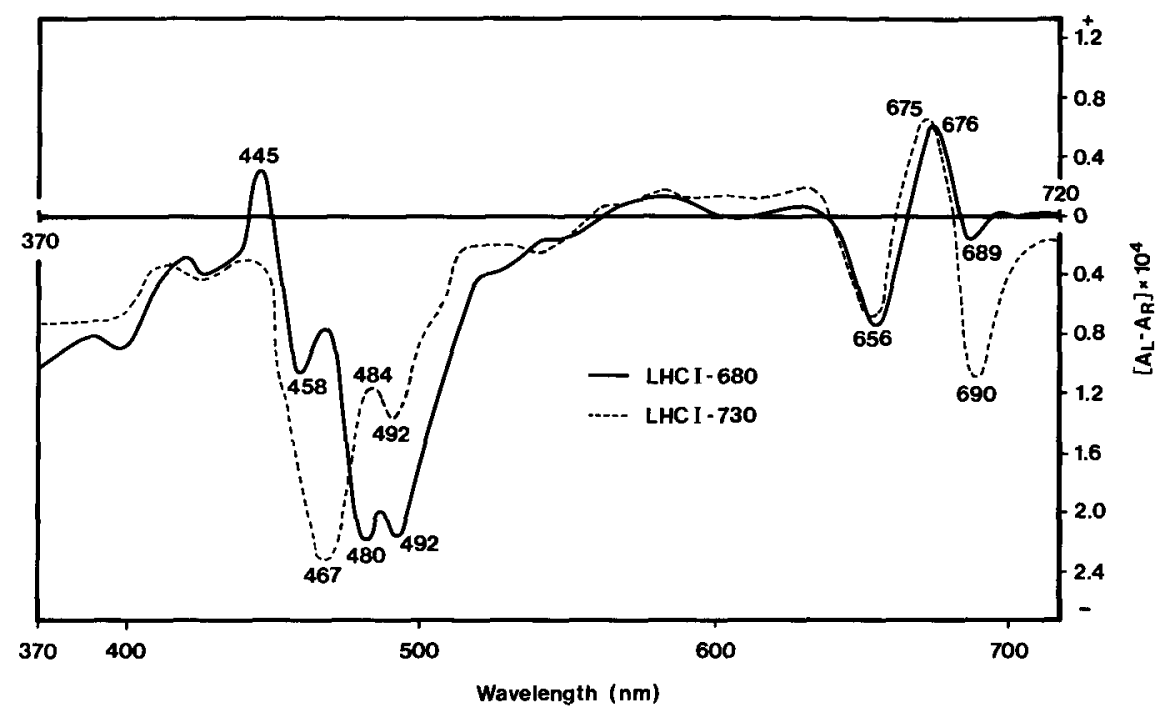

Figure 10. Circular dichroism spectra of LHCI-680 (MA3) and LHCI-730 (MA2). Bands A1, A2 and MA2 had the same spectra (LHCI-730); bands A3 and MA3 had the same spectrum as LHCl-680. Chlorophyll concentration was $10 \mu \mathrm{g} \cdot \mathrm{ml}^{-1}$, slit width $=1 \mathrm{~nm}$.

cal to each other (Figure 10). The CD spectra from LHCI-680 and LHCI-730 were drastically different from those of the PSI reaction centrecontaining preparations, mainly because of the stronger optical activity in the $450-500 \mathrm{~nm}$ spectral region. The main difference between LHCI-680 and LHCI-730 was in the 689-690 $\mathrm{nm}$ negative signal which was much smaller in

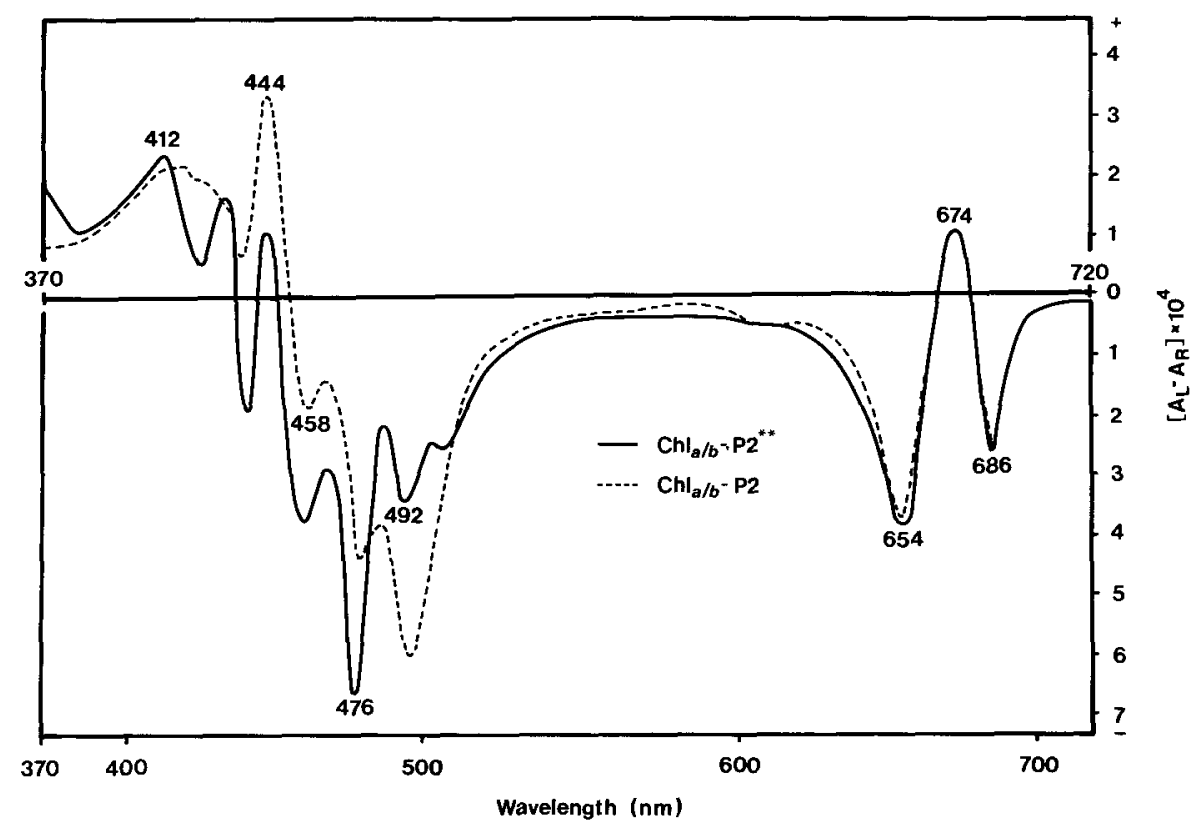

Figure 11. Circular dichroism spectra of both $\mathrm{Chl}_{a / b}-\mathrm{P} 2$ and $\mathrm{Ch}_{a / b}-\mathrm{P} 2^{* *}$ are shown. Chlorophyll concentration was $20 \mu \mathrm{g} \cdot \mathrm{ml}^{-1}$, slit width $=0.5 \mathrm{~nm}$. 


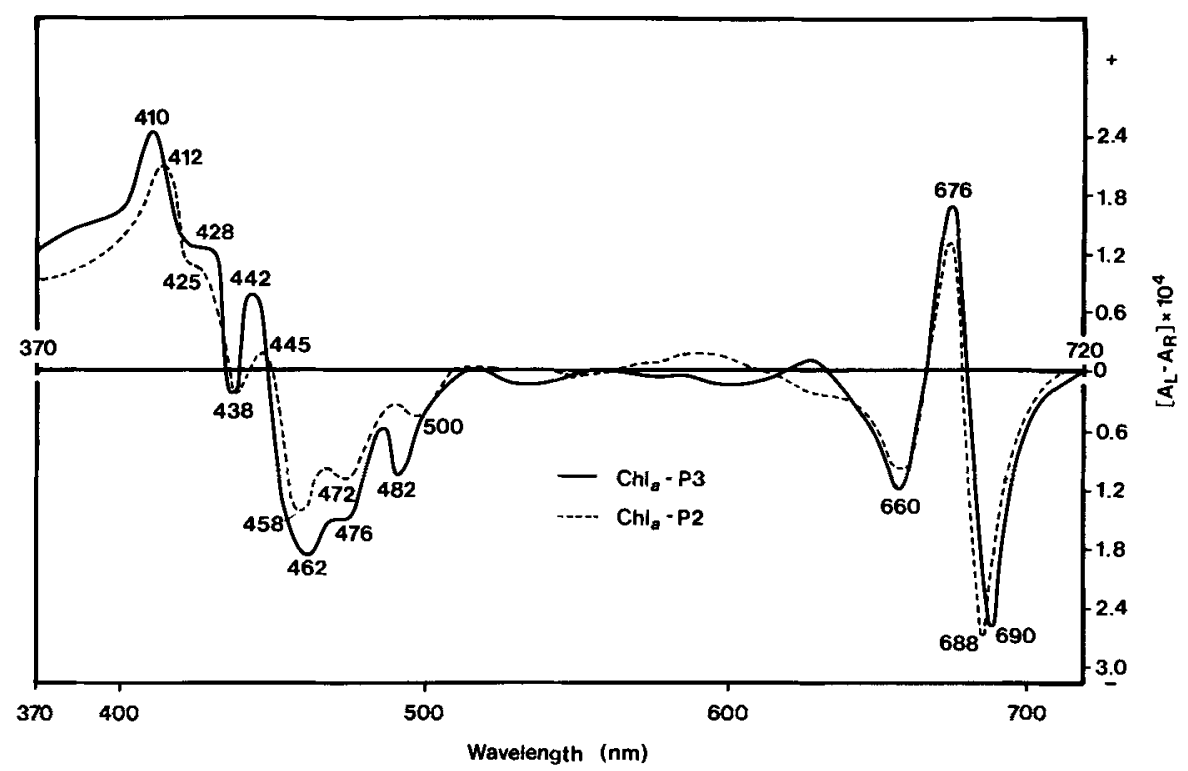

Figure 12. Circular dichroism spectra of $\mathrm{Chl}_{a}-\mathrm{P} 2$ and $\mathrm{Chl}_{a}-\mathrm{P} 3$ bands eluted from gel slices. Chlorophyll concentration $=10 \mu \mathrm{g} \cdot \mathrm{ml}^{-1}$, slit width $=1 \mathrm{~nm}$.

the former. The positive signal at $675-676 \mathrm{~nm}$ and the negative one at $655-656 \mathrm{~nm}$ were, in contrast, equally strong. LHCI-730 showed two strong negative peaks at 492 and $467 \mathrm{~nm}$ and a shoulder at about $460 \mathrm{~nm}$. LHCI-680 did not show the $467 \mathrm{~nm}$ signal, while the $492 \mathrm{~nm}$ peak was more intense and a new peak was present at $480 \mathrm{~nm}$. A minor peak was also seen at 458 $\mathrm{nm}$ and may correspond to the $460 \mathrm{~nm}$ shoulder in LHCI-730. A $445 \mathrm{~nm}$ positive signal which was almost absent in LHCI-730, was seen in LHCI-680 (Figure 10).

$\mathrm{Chl}_{a / b}-\mathrm{P} 2$ appeared in two forms after nondenaturing SDS-PAGE, the higher molecular weight one $\left(\mathrm{Chl}_{a / b}-\mathrm{P} 2^{* *}\right)$ being an oligomer of the other $\left(\mathrm{Chl}_{a / b}-\mathrm{P} 2\right)(2,11,12,29,36)$. Both $\mathrm{Ch}_{a / b}-\mathrm{P} 2$ containing bands were eluted from the gels and examined for CD spectra (Figure 11). The spectra of the two forms were very similar in the red region with two negative signals at 686 and $654 \mathrm{~nm}$, and a weak positive one at $674 \mathrm{~nm}$. Some differences in the fine structure were perhaps present in the $640-650 \mathrm{~nm}$ range. Although the same signals were present in the spectra of both $\mathrm{Ch}_{a / b}-\mathrm{P} 2$ forms, large differences were seen in the relative intensity of the bands. In particular, the $476 \mathrm{~nm}$ signal was more intense in the oligomeric form, while the ones at 492 and $458 \mathrm{~nm}$ were increased in $\mathrm{Chl}_{a / b}-\mathrm{P} 2$.

$\mathrm{Chl}_{a}-\mathrm{P} 2, \mathrm{Chl}_{a}-\mathrm{P} 3$ and $\mathrm{Chl}_{a / b}-\mathrm{P} 3$ had similar electrophoretic mobilities and it was difficult to excise the bands without cross contamination. To reduce contamination of $\mathrm{Chl}_{a}-\mathrm{P} 2$ and $\mathrm{Chl}_{a}-\mathrm{P} 3$ by $\mathrm{Chl}_{a / b}-\mathrm{P} 3$, gel slices were used only from those experiments in which most of the PSI-associated chlorophyll was in the $\mathrm{Chl}_{a}-\mathrm{Pl}^{*}$ position so that the amount of the $\mathrm{Chl}_{a / b}-\mathrm{P} 3$ band was very low. The CD spectra of $\mathrm{Chl}_{a}-\mathrm{P} 2$ and $-\mathrm{P} 3$ were very similar with two negative signals (at 688-690 and $660 \mathrm{~nm}$ ) and a positive one at $676 \mathrm{~nm}$ (Figure 12). The spectra were also similar in the $450-500 \mathrm{~nm}$ range, where three negative signals were seen in both cases, peaking at 482,476 and $462 \mathrm{~nm}\left(\mathrm{Chl}_{a}-\mathrm{P} 2\right)$ and 500,472 and $458 \mathrm{~nm}\left(\mathrm{Chl}_{a}-\mathrm{P} 3\right) . \mathrm{Chl}_{a}-\mathrm{P} 2$ and/or $\mathrm{Ch}_{a}-\mathrm{P} 3$ have been suggested to contain the PSII reaction centre. When their CD spectra were compared with those from the PSI reaction centre-containing chlorophyll-proteins, many differences could be seen, particularly the low intensity of the positive $445 \mathrm{~nm}$ signal in $\mathrm{Ch}_{a}-\mathrm{P} 2$ and -P3, while the $660 \mathrm{~nm}$ negative signal was not present in PSI. 


\section{DISCUSSION}

The chlorophyll-protein composition of the two native PSI preparations, $\mathrm{Chl}_{a}-\mathrm{P} 1^{*}$ and PSI$110(30)$, shows a common pattern characterized by the presence of three chlorophyll-proteins: $\mathrm{Chl}_{a}$-P1, LHCI-730 and LHCI-680. Other green bands represent oligomers of LHCI-730 (e.g., the Al band) or chlorophyll not bound specifically to the protein (MA1, FP) as indicated by the absence of extrinsic optical activity by $\mathrm{CD}$ analysis and by the shift of the $678 \mathrm{~nm}$ peak of the absorption spectra to $669 \mathrm{~nm}$. A suryey of the chlorophyll-proteins and their complexes is given in Table $\mathrm{I}$.

$\mathrm{Chl}_{a}-\mathrm{Pl}$, also called CP1, contains the PS1 reaction centre $(P-700)(3)$ and is composed of apoproteins of about $67 \mathrm{kD}$ which bind only chlorophyll $a$. The $77 \mathrm{~K}$ fluorescence emission is at $720 \mathrm{~nm}$ and the red absorption peak is at $678 \mathrm{~nm}$.

LHCI-730 is the chlorophyll-protein in the $\mathrm{A} 1$ and $\mathrm{A} 2$ bands from $\mathrm{Chl}_{a}-\mathrm{P} 1^{*}$, the $\mathrm{MA} 2$ band from PSI-110 and the $\mathrm{Chl}_{a / b}-\mathrm{P} 3$ band from bundle sheath thylakoids. Its $77 \mathrm{~K}$ fluorescence emission is around $730 \mathrm{~nm}$ and the absorption peak in the red is at $673-74 \mathrm{~nm}$. It contains three polypeptides of molecular weights $24,22.5$ and $21 \mathrm{kD}$. Both chlorophyll $a$ and $b$ are bound in the ratio 3-4. The two proteins of 38 and $42 \mathrm{kD}$ in the urea gel from the MA2 band are not thought to be components of the complex since they were not present in the $\mathrm{A} 1$ and $\mathrm{A} 2$ bands after re-electrophoresis of $\mathrm{Chl}_{\alpha}-\mathrm{P} 1^{*}$ (Figure $4 \mathrm{~A}$, track 4 ). These proteins have been removed from a PSI-110 preparation from spinach without any change in the chlorophyllprotein pattern (23). LHCI-730 has spectral characteristics and a polypeptide composition similar to previously described LHCI preparations $(23,30)$.

LHCI-680 isolated from either $\mathrm{Chl}_{a}-\mathrm{P} 1^{*}$ or PSI-110, fluoresces at $680 \mathrm{~nm}$ and has a high chlorophyll $b$ content (chlorophyll $a / b$ ratio about 1-1.2). These spectral characteristics are similar to those of the main light-harvesting complex $\left(\mathrm{Chl}_{a / b}-\mathrm{P} 2\right)$, but the different $\mathrm{CD}$ spectra and polypeptide composition clearly distinguish between LHCI-680 and $\mathrm{Chl}_{a / b}-\mathrm{P} 2$. SDS-PAGE of the excised LHCI-680 band in dissociating conditions, shows two polypeptides of 25 and $20 \mathrm{kD}$ but one may be a contaminant. In non-denaturing SDS-PAGE, LHCI-680 has the same mobility as $\mathrm{Chl}_{a / b}-\mathrm{P} 2$, so that when chlorophyll-proteins are solubilized and electrophoresed without prior separation of the photosystems, $\mathrm{Chl}_{a / b}-\mathrm{P} 2$ and LHCI-680 are superimposed on the gel. This is confirmed by the different polypeptide pattern obtained when the two forms $\left(\mathrm{Chl}_{a / b}-\mathrm{P} 2\right.$ and $\left.\mathrm{Chl}_{a / b}-\mathrm{P}{ }^{* *}\right)$ are reelectrophoresed in denaturing conditions. $\mathrm{Chl}_{a / b}$ $\mathrm{P} 2$ contains the same three polypeptides present in $\mathrm{Chl}_{a / b}-\mathrm{P} 2^{* *}$, plus the 20 and $25 \mathrm{kD}$ proteins also present after re-electrophoresis of the LHCI-680 band (Figure 4B, see also ref. 11). The CD spectra support this conclusion, since the very intense $492 \mathrm{~nm}$ negative signal characteristic of LHCI-680 is increased in the spectrum from $\mathrm{Chl}_{a / b}-\mathrm{P} 2$ compared with the one from $\mathrm{Chl}_{a / b}-\mathrm{P} 2^{* *}$. On the other hand, the changes in the intensity of the $492 \mathrm{~nm}$ signal might be caused by conformational changes due to the different aggregation states of $\mathrm{Chl}_{\alpha / b}-\mathrm{P} 2$ (15).

Resolution of the light-harvesting $\mathrm{Chl}_{a / b}$ protein into two different chlorophyll-proteins $\mathrm{Chl}_{a / b}-\mathrm{P} 1$ and $\mathrm{Chl}_{a / b}-\mathrm{P} 2$ has been reported (28), but $\mathrm{Chl}_{a / b}-\mathrm{P} 1$ is not the same as LHCI-680, since its apoprotein has a molecular weight very similar to one of $\mathrm{Chl}_{a / b}-\mathrm{P} 2$ (see Table I). Furthermore, $\mathrm{Ch}_{a / b}-\mathrm{Pl}$ is not present in the bundle sheath chloroplast of maize $(11,12)$ while $\mathrm{LHCI}$ 680 is, as confirmed by the presence of the 20 and $25 \mathrm{kD}$ polypeptides after re-electrophoresis of $\mathrm{Chl}_{a / b}-\mathrm{P} 2$ (Figure 4B, tracks 3,4).

Non-denaturing SDS-PAGE has been used as a quantitative method to determine the relative amounts of the PSI- and PSII-associated pigments, on the basis of the assignment of $\mathrm{Chl}_{a}-\mathrm{Pl}$ and $\mathrm{Chl}_{a}-\mathrm{Pl}$ * to PSI and of all other chlorophyll-proteins to PSII $(4-6,26)$. The recent finding (11) that LHCI-730 (synonyms: $\mathrm{Ch}_{a / b}-\mathrm{P} 2^{*}, \mathrm{LHCP} 2$ or $\left.\mathrm{Chl}_{a / b}-\mathrm{P} 3\right)$ is a PSI lightharvesting chlorophyll-protein, and that part of the chlorophyll migrating in the position of $\mathrm{Ch}_{a / b}-\mathrm{P} 2$ (LHCP3) is actually bound to LHCI680 , indicates that this method would underestimate the amount of chlorophyll associated with PSI.

The separation of two $\mathrm{LHCI}$ forms fluorescing at 680 and $730 \mathrm{~nm}$ (LHCIa and LHCIb, respectively) by gradient ultracentrifugation, has been 
recently reported (24). LAM et al. found less optical activity in the LHCIa compared with LHCIb, although the CD spectra were similar. They hypothesized a lower degree of pigment organization in LHCla (24). In contrast, LHCI730 and LHCI-680 show almost identical optical activity, but the $\mathrm{CD}$ signals peak at different wavelengths in the spectra from the two preparations (Figure 10).

A comparison of the CD spectra of the native and antenna-depleted PSI preparations shows that the negative peak at $653 \mathrm{~nm}$ is due to the LHCI contribution. Our spectra differ from those in (21) and (24) who report the wavelength of this signal at $647 \mathrm{~nm}$. The wavelength accuracy of the instrument that we have used has been checked (see section 2.4) and the measurements repeated several times. An even longer wavelength peak, at $656 \mathrm{~nm}$, was found in $\mathrm{Chl}_{a}-\mathrm{PI}^{*}$ (Figure 9), probably indicating a more native conformation. This negative peak probably includes the contribution of a short wavelength absorbing chlorophyll $a$ species (16), comparable to that present in the spectra of $\mathrm{Chl}_{a}-\mathrm{P} 2$ and -P3 which only bind chlorophyll $a$. This signal is also present in $\mathrm{Chl}_{a}-\mathrm{P} 2$ and -P3 obtained from the barley mutant chlorina $f 2$ lacking chlorophyll $b$ (BASSI, unpublished results).

This CD study of chlorophyll-proteins emphasizes the role of carotenoids since a strong optical activity was present in the $450-500 \mathrm{~nm}$ wavelength range. This is particularly evident in the light-harvesting type chlorophyll-proteins $\left(\mathrm{Chl}_{a / b}-\mathrm{P} 2, \mathrm{Chl}_{a / b}-\mathrm{P} 2^{* *}\right.$, LHCI-680, and LHCI730 ), while these contributions were less pronounced for those chlorophyll-proteins which have been demonstrated or inferred to belong to PSI or PSII reaction centres. On the other hand, the presence of 503 and 482 positive signals in both antenna-depleted PSI preparations, indicates the involvement of carotenoids in the PSI reaction centre. Similar considerations apply for $\mathrm{Chl}_{a}-\mathrm{P} 2$ and -P3.

There are no clear explanations for the differences in the CD spectra of chloroplasts and single chlorophyll-proteins or solubilized membranes. Unsolubilized thylakoids not only have a more intense $\mathrm{CD}$ signal but they are also qualitatively different in their shape $(19,34)$.
Tentative explanations propose that differential light scattering (34) or specific chlorophyll-chlorophyll interactions (19) are responsible for the observed CD pattern of the chloroplasts. Whatever the cause of these differences, CD spectra from different isolated chlorophyll-proteins show unique patterns and can be useful for their identification and characterization.

In Chlamydomonas (41), the double mutant F54-14 lacking Chl ${ }_{a}-\mathrm{Pl}$ and ATPase has been exploited to isolate a PSI light-harvesting complex (CP0), consisting of 5 polypeptides (27.5, $27,25,23$ and $19 \mathrm{kD}$ ). It fluoresces at $707 \mathrm{~nm}$ at $77 \mathrm{~K}$ and could be equivalent to a combination of LHCI-680 and LHCI-730 in maize. Two of these polypeptides $(27.5,27 \mathrm{kD})$ comigrate with $\mathrm{Ch1}_{a / b}-\mathrm{P} 2$ when thylakoids are anaylyzed

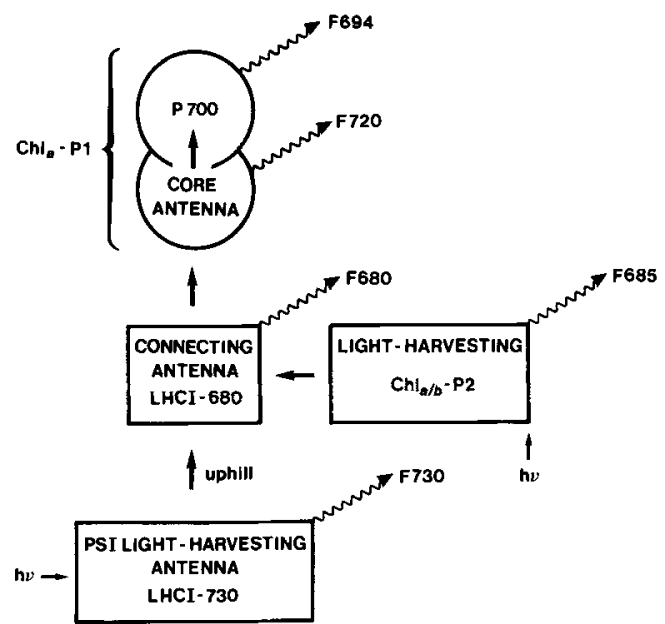

Figure 13. Proposed scheme for energy transfer to photosystem I in higher plants. Two light-harvesting antennae are specifically associated with the PSI reaction centre, and the phosphorylated "monomeric" form of $\mathrm{Chl}_{a / h}-\mathrm{P} 2$ can also transfer energy to $P-700$ via the $\mathrm{LHCl}-680$ connecting antenna. In the absence of $\mathrm{Chl}_{a}-\mathrm{Pl}$, fluorescence is emitted in increased yield as a result of downhill energy transfer to $\mathrm{LHCl}-730$. In the absence of LHCI-730, a low yield of fluorescence emission at $720 \mathrm{~nm}$ is predicted. If LHCI-680 is missing, we predict an increase in fluorescence yield at $685 \mathrm{~nm}$ from $\mathrm{Chl}_{a / b}-\mathrm{P} 2$, and at $720 \mathrm{~nm}$ from $\mathrm{Chl}_{a}-\mathrm{P} 1$. If both LHCI-680 and LHCI-730 are missing, there should be a low fluorescence yield at 720 , as from the thylakoids of the chlorophyll $b$-less barley mutant, chlorina $f 2$ (38). 
by lithium SDS-PAGE (18), as is the case for LHCI-680 in maize. The mutant F-14 lacks $\mathrm{Chl}_{a}-\mathrm{Pl}$ and fluoresces at $707 \mathrm{~nm}$. The mutant $\mathrm{AC} 40$ lacks the antenna $\mathrm{CP} 0$ and emits fluorescence with a lower yield at $717 \mathrm{~nm}$, i.e., from $\mathrm{Chl}_{a}-\mathrm{P} 1$. The double mutant has no long wavelength emission and fluoresces at $686 \mathrm{~nm}$. Thus CP0 fluoresces at $707 \mathrm{~nm}$ in vivo unless the energy can be transferred to the PSI reaction centre $\mathrm{Chl}_{a}-\mathrm{P} 1$. In the mutant $\mathrm{y}-1 \mathrm{p}$, which lacks 4 of the polypeptides of CP0, the PSI antenna size is decreased, leading to an increase in fluorescence yield at $686 \mathrm{~nm}$ from $\mathrm{Chl}_{a / b}-\mathrm{P} 2$. This is interpreted to mean that the four missing polypeptides form a connecting antennae between the core antenna of $\mathrm{Chl}_{\mathrm{a}}-\mathrm{Pl}$ and the light-harvesting LHCI-707 antenna, as well as $\mathrm{Chl}_{\alpha / h}-\mathrm{P} 2$ (22).

Using this model and the apparent homology of the photosystem I components in Chlamydomonas and maize, LHCI-680 would correspond to the connecting antenna, and LHCI-730 to the peripheral light-harvesting antenna (Figure 13). With this model, we can interpret the fluorescence emission properties of two types of barley mutants. Mutant viridis- $z b^{63}(38)$ lacks $\mathrm{Chl}_{a}-\mathrm{P} 1$ but has $\mathrm{Chl}_{a / b}-\mathrm{P} 2, \mathrm{LHCI}-680$ and LHCI-730, and has an increased $732 \mathrm{~nm}$ fluorescence emission from $\mathrm{LHCI}-730$ which, in the absence of the reaction centre is no longer quenched. The thylakoids of chlorina 2 mutants (29) lack $\mathrm{Chl}_{a / b}-\mathrm{P} 2$, LHCI-680, and LHCI-730. They emit fluorescence at $77 \mathrm{~K}$ from the $\mathrm{Chl}_{a}-\mathrm{P} 1$ core antenna at $720 \mathrm{~nm}$.

We thus propose that in higher plants, the following sequence of energy transfer to PSI occurs: LHCI-730 $\rightarrow$ LHCI-680 $\rightarrow \mathrm{Chl}_{a}-\mathrm{P} 1$ (Figure 13). This model is consistent with the sequential removal of first LHCI-730 and then LHCI-680 from $\mathrm{Chl}_{a}-\mathrm{P} 1^{*}$, which implies that LHCI-680 is closer to the reaction centre and more tightly bound to it. In addition, the phosphorylated "monomeric" form of $\mathrm{Ch}_{a / b}-\mathrm{P} 2$ can also transfer energy to $P-700$ via the LHCI-680 connecting antenna (11). LHCI-730 contains a long wavelength chlorophyll $a$ species (Ca690), as shown by the $\mathrm{CD}$ spectrum (Figure 10 ) and acts as a sink for PSI, since energy transfer to LHCI-680 is uphill (see references 13, 30 and 35 for discussion about the occurrence of uphill energy transfer). This could function to concentrate energy for PSI and to protect the reaction centre from photo-oxidation.

The existence of a connecting antenna is also consistent with the efficient energy transfer from $\mathrm{Chl}_{a / b}-\mathrm{P} 2$ to PSI in bundle sheath membranes of maize (11). In agranal chloroplasts $\mathrm{Chl}_{a / b}-\mathrm{P} 2$ was seen mainly in its monomeric form after SDS-PAGE. It is possible that $\mathrm{Ch}_{a / b}-\mathrm{P} 2$ monomers localized in stroma lamellae transfer energy to PSI via LHCI-680 whereas $\mathrm{Ch}_{a / b}-\mathrm{P} 2$ oligomers found in mesophyll chloroplasts, transfer energy to PSII in appressed grana regions. The polypeptide of $7.8 \mathrm{kD}$ found in $\mathrm{Chl}_{a / b}-\mathrm{P} 2$ oligomer may be involved in the interconversion of $\mathrm{Chl}_{a / b}-\mathrm{P} 2$ forms (11).

A regulatory mechanism for the distribution of the excitation energy between PSI and PSII during state 1 -state 2 transitions $(17,31)$ has been proposed which involves phosphorylation of $\mathrm{Chl}_{a / b}-\mathrm{P} 2$ in grana, its disconnection from PSII reaction centres, and subsequent migration into stroma lamella $(1,8,10,20,25,32,40)$, where it can transfer energy to PSI $(11,27)$ via the LHCI-680 connecting antenna. We expect from the scheme in Figure 13, that phosphorylation of $\mathrm{Chl}_{a / b}-\mathrm{P} 2$ in a mutant lacking LHCI680 would result in an increased fluorescence yield at $685 \mathrm{~nm}$ at $77 \mathrm{~K}$, in contrast to the decrease at $685 \mathrm{~nm}$ in wild type.

\section{ACKNOWLEDGEMENTS}

We wish to thank Professor DITER vON WETTSTEIN for his encouragement during the course of this work and for critically reading the manuscript. Dr. URSUla HinZ, GuNILla HøYer-HANSEN, GAMINI KANNANGARA, SIMON GOUGH are thanked for helpful discussions. KIRSTEN MICHELSEN and SVEN HARNUNG, H.C. Ørsted Institute, kindly made available the Roussel-Jouen Dichrograph III spectropolarimeter. We are grateful to NINA RASMUSSEN for drawing the figures, and ANNSOFI STEINHOLTZ for printing the color photographs. ROBERTO BASSI is grateful for financial support during the course of this work from the Department of Biology, University of Padova. 


\section{REFERENCES}

1. Allen, J. F., J. Bennett, K. E. Steinback \& C. J. ARNTZEN: Chloroplast protein couples plastoquinone redox state to distribution of excitation energy between photosystems. Nature 291, 25-29 (1981)

2. ANDERSON, J. M., C. WALDRON \& S. W. THORNE: Chlorophyll-protein complexes of spinach and barley thylakoids. FEBS Lett. 92, 227-233 (1978)

3. ANDERSON, J. M.: P-700 and polypeptide profile of chlorophyll-protein complexes of spinach and barley thylakoids. Biochim. Biophys. Acta 591, 113-126 (1980)

4. ANDERSON,J. M.: Chlorophyll-protein complexes of higher plants chloroplasts: distibution, stoichiometry and organization on the photosynthetic unit. FEBS Lett. 117, 327-331 (1980)

5. ANDERSON, J. M.: Consequences of spatial separation of photosystem 1 and 2 in the thylakoid membranes of higher plant chloroplasts. FEBS Lett. 124, 1-10 (1981)

6. ANDERSSON, B.\& J. M. ANDERSON: Lateral heterogeneity in the distribution of the chlorophyll-protein complexes of the thylakoid membranes of spinach chloroplasts. Biochim. Biophys. Acta 593, 421-440 (1980)

7. ANDERSSON, B., J. M. ANDERSON \& I. J. Ryrie: Transbilayer organization of the chlorophyll-proteins of spinach thylakoids. Eur. J. Biochem. 123, 465-472 (1982)

8. ANDERSSON, B., H. E. AKerLund, B. JeRgil \& C. LARSSEN: Differential phosphorylation of the light harvesting complex in appressed and non-appressed regions of the thylakoid membrane. FEBS Lett. 149, 181-185 (1982)

9. ARNON, D. I.: Copper enzymes in isolated chloroplasts. Polyphenoloxidase in Beta vulgaris. Plant Physiol. 24, 1-14 (1949)

10. ARntzen, C. J.: Dynamic structural features of chloroplast lamellae. In: Current Topics in Bioenergetics. D. R. Sanadi \&' L. P. Vernon Eds. Academic Press, N. Y. Vol. VIII, 111-160 (1978)

11. R. BASSI: Spectral properties and polypeptide composition of the chlorophyll-proteins from thylakoids of granal and agranal chloroplasts of maize (Zea mays L. ). Carlsberg Res. Commun. 50, 127-143 (1985)

12. Bassi, R., A. Dal Belin-Peruffo, R. Barbato \& R. GHISI: Differences in chlorophyll-protein complexes and composition of polypeptides between thylakoids from bundle sheath and mesophyll cells in maize. Eur. J. Biochem. 146, 589-595 (1985)

13. BenNoun P. \& H. Jupin: Spectral properties of system I-deficient mutants of Chlamydomonas reindardi. Possible occurrence of uphill energy transfer. Biochim. Biophys. Acta 440, 122-130 (1976)

14. Boardman, N. K. \& J. M. Anderson: Composition, structure and photochemical of developing and mature chloroplasts. In: Chloroplast Development. G. Akoyunoglou et al. Eds. Elsevier pp. 1-14 (1978)

15. Brecht, E., S. Demeter \& A. Faludi-Daniel: Fine structure of the circular dichroic spectrum of the light-harvesting chlorophyll $a / b$-protein complex reaggregated in vitro. Photobiochem. Photobiophys. 3, 153-157 (1981)

16. BROWN, J. S.: Spectroscopy of chlorophyll in photosynthetic membranes. Carnegie Inst. Year Book 82, 46-52 (1983)

17. Chow, W. S., A. Telfer, D. J. Chapman \& J. BARBER: State 1-state 2 transition in leaves and its association with ATP induced chlorophyll fluorescence quenching. Biochim. Biophys. Acta 638, 60-68 (1981)

18. Delepelaire, P. \& N. H. Chua: Electrophoretic purification of chlorophyll $a / b$ protein complexes from Chlamydomonas reinhardii and spinach and analysis of their polypeptides compositions. J. Biol. Chem. 256, 9300-9307 (1981)

19. R. P. F. Gregory \& S. Raps: The differential scattering of circularly polarized light by chloroplasts and evaluation of their true circular dichroism. Biochem. J. 142, 193-201 (1974)

20. Haworth, P., D. J. Kyle, P. Horton \& C. J. ARNTZEN: Chloroplast membrane protein phosphorylation. Photochem. Photobiol. 36, 743-748 (1982)

21. Haworth, P., J. L. WATSON \& C. J. ARNTZEN: The detection, isolation and characterization of a light harvesting complex which is specifically associated with photosystem I. Biochim. Biophys. Acta 724, 151-158 (1983)

22. Ish-Shalom, D. \& I. OhaD: Organization of chlorophyll-protein complexes of photosystem $I$ in Chlamydomonas reinhardii. Biochim. Biophys. Acta 722, 498-507 (1983)

23. Lam, E., W. Ortiz, S. Mayfield \& R. Malkin: Isolation and characterization of a light harvesting chlorophyll $a / b$ protein complex associated with photosystem I. Plant. Physiol. 74, 650-655 (1984)

24. LAM, E., W. ORTIZ \& R. MALKIN: Chlorophyll $a / b$ proteins of photosystem I. FEBS Lett. 168, 10-14 (1984)

25. LARSSON, U. K., B. Jergil \& B. ANDERSSON: Changes in the lateral distribution of the light harvesting chlorophyll- $a / b$-protein complex induced by its phosphorylation. Eur. J. Biochem. 136, 25-29 (1983)

26. LEONG, T. Y. \& J. M. ANDERSON: Adaptation of 
the thylakoid membrane of pea chloroplasts to light intensities. I: Study on the distribution of chlorophyll-protein complexes. Photosynth. Res. 5, 105-115 (1984)

27. Kyle, D. J., T. Y. Kuang, J. L. Watson \& C. J. ARNTZEN: Movement of a sub-population of the light harvesting complex (LHCII) from grana to stroma lamellae as a consequence of its phosphorylation. Biochim. Biophys. Acta 765, 89-96 (1984)

28. Machold, O. \& A. Meister: Resolution of the light harvesting chlorophyll- $a / b$ protein of Vicia faba chloroplasts into two different chlorophyllprotein complexes. Biochim. Biophys. Acta 546, 472-480 (1979)

29. Machold, O., D. J. Simpson \& B. L. Møller: Chlorophyll-proteins of thylakoids from wild-type and mutants of barley (Hordeum vulgare L. ). Carlsberg Res. Commun. 44, 235-254 (1979)

30. Mullet, J. E., J. J. Burke \& C. J. ARnTzen: Chlorophyll-proteins of photosystem I. Plant Physiol. 65, 814-822 (1980)

31. Murata, N.: Control of excitation transfer in photosynthesis. V. Correlation of membrane structure to regulation of excitation transfer between two pigment systems in isolated spinach chloroplasts. Biochim. Biophys. Acta 245, 365372 (1971)

32. Olive, J., F. A. Wollman, P. Bennoun \& M. RECOUVREUR: Ultrastructure of thylakoid membranes in $C$. reinhardii: evidence for variations in the partition coefficient of the light harvesting complex containing particles upon membrane fracture. Arch. Biochem. Biophys. 208, 456-467 (1981)

33. Ortiz, W., E. LAM, M. Ghirardi \& R. Malkin: Antenna function of a chlorophyll $a / b$ protein complex of photosystem I. Biochim. Biophys. Acta 766, 505-509 (1984)

34. Philipson, K. D. \& K. Sauer: Light-scattering effects on the circular dichroism of chloroplasts. Biochemistry 12, 3454-3458 (1973)

35. Razjivin, A.P., R. V. Danielius, R. A. Gadonas, A. YU. Borisov \& A. S. PISKarsKas: The study of excitation transfer between light-harvesting antenna and reaction center in chromatophores from purple bacterium Rhodospirillum rubrum by selective picosecond spectroscopy. FEBS Lett. 143, 40-44 (1982)

36. REMY, R. \& F. AMBART-BRETTEVILLE: Evidence for a chlorophyll $a / b$-protein complex associated with photosystem I. FEBS Lett. 170, 174-180 (1984)

37. SHEPANSKI, J.F. \& R. S. KNox: Circular dichroism and other optical properties of antenna chlorophyll proteins from higher plants. Isr. J. Chem. 21, 325-331 (1981)

38. Simpson, D. J. \& D. Von WetTstein: Macromolecular physiology of plastids XIV. Viridis mutants in barley: Genetic, fluoroscopic and ultrastructural characterization. Carlsberg Res. Commun. 45, 283-314 (1980)

39. ThORnber, P.: Chlorophyll-proteins: Light harvesting and reaction center components of plants. Ann. Rev. Plant Physiol. 26, 127-158 (1975)

40. Torti, F., P. D. Gerola \& R. C. Jennings: Membrane phosphorylations leads to the partial detachment of the chlorophyll $a / b$ protein from photosystem II. Biochim. Biophys. Acta 767, 321-325 (1984)

41. Wollman, F. A. \& P. BenNoun: A new chlorophyll-protein complex related to photosystem I in Chlamydomonas reinhardii. Biochim. Biophys. Acta $680,352-360$ (1982) 